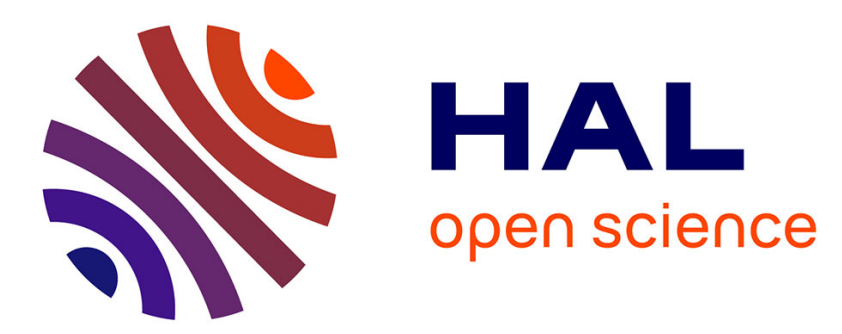

\title{
Significance of random illite-vermiculite mixed layers in Pleistocene sediments of the northwestern Atlantic Ocean
}

P Vanderaveroet, Viviane Bout-roumazeilles, N Fagel, H Chamley, J F Deconinck

\section{To cite this version:}

P Vanderaveroet, Viviane Bout-roumazeilles, N Fagel, H Chamley, J F Deconinck. Significance of random illite-vermiculite mixed layers in Pleistocene sediments of the northwestern Atlantic Ocean. Clay Minerals, 2000, 35 (4), pp.679-691. hal-03281922

\section{HAL Id: hal-03281922 https://hal.science/hal-03281922}

Submitted on 8 Jul 2021

HAL is a multi-disciplinary open access archive for the deposit and dissemination of scientific research documents, whether they are published or not. The documents may come from teaching and research institutions in France or abroad, or from public or private research centers.
L'archive ouverte pluridisciplinaire HAL, est destinée au dépôt et à la diffusion de documents scientifiques de niveau recherche, publiés ou non, émanant des établissements d'enseignement et de recherche français ou étrangers, des laboratoires publics ou privés. 


\title{
Significance of random illite-vermiculite mixed layers in Pleistocene sediments of the northwestern Atlantic Ocean
}

\author{
P. VANDERAVEROET ${ }^{1}{ }^{*}$, , V. BOUT-ROUMAZEILLES ${ }^{1}$, N. FAGEL $^{2}$, \\ H. CHAMLEY ${ }^{1}$ AND J. F. DECONINCK ${ }^{1}$
}

${ }^{I}$ Sédimentologie et Géodynamique, UMR 8577 CNRS, SN5, Université de Lille I, 59655 Villeneuve d'Ascq Cedex,
France, ${ }^{2}$ Clay and Mineralogy Department, Université de Liège, Sart-Tilman, B4000 Liège, Belgium

*E-mail: Patricia.Vanderaveroet@univ-lille1.fr

\begin{abstract}
The clay mineralogy of Pleistocene sediments of eleven sediment cores at three ODP sites from $30^{\circ} \mathrm{N}$ to $60^{\circ} \mathrm{N}$ northwestern Atlantic Ocean has been investigated. The sediments are characterized by the presence of random illite-vermiculite mixed layers (I-V) (up to 32\% of the clay mineral assemblage). The I-V clays are much more abundant during interglacial periods than during glacial ones. They are attributed to detrital supply through erosion of high-latitude continental areas from which they are derived mainly from chemical weathering of micaceous phyllosilicates. Their spatial distribution and the specific conditions for their formation through weathering suggest that I-V mixed layers are mainly derived from the Canadian Shield. They were transported from their source to marine deposition areas by rivers, deep water masses or nepheloid layers. Due to the specific conditions required for the formation of I-V, its occurrence and abundance are used as a palaeoclimate and palaeocirculation proxy for northwestern Atlantic Pleistocene sediment.
\end{abstract}

KEYWORDS: Pleistocene, Atlantic Ocean, glacial/interglacial, illite-vermiculite mixed layers.

Clay mineral investigations of Cenozoic sediments have been performed on numerous North Atlantic Ocean coring and drilling sites starting from DSDP Leg 11 (Lancelot et al., 1972). Drilled and cored holes were studied from: DSDP Leg 43 (Koch \& Rothe, 1979), DSDP Leg 44 (Flood, 1978), DSDP Leg 47 (Chamley et al., 1979), DSDP Leg 48 (Cassat, 1979), DSDP Leg 50 (Chamley et al., 1980), ODP Leg 105 (Thiébault et al., 1989), ODP Legs 150 and 150X 
(Deconinck \& Vanderaveroet, 1996; Vanderaveroet \& Deconinck, 1997), CSS Hudson cruise (Fagel et al., 1996) and Suroit 1990 Paleocinat cruise (Bout-Roumazeilles, 1995).

From Eocene to late Pleistocene, the clay mineralogical trend is characterized by an increase of rock-derived clay minerals such as illite and chlorite associated with random mixedlayer minerals, at the expense of soil-derived minerals such as smectite (Chamley, 1979). In Eocene sediments, smectite-rich assemblages, probably largely reworked from poorly-drained soils, dominated the clay assemblage, reflecting the warm conditions prevailing during this period. Close to the Eocene-Oligocene boundary and during the early Oligocene, a change appeared in the sedimentation: the proportions of clay minerals issuing from mechanical alteration increased in relation to the global cooling induced by the Antarctic glaciation (Robert, 1992). From Oligocene to Pleistocene, percentages of illite and chlorite increased in successive steps whereas proportions of smectite and often of kaolinite decreased (Chamley, 1979).

In the northwestern Atlantic Ocean between $30^{\circ} \mathrm{N}$ and $60^{\circ} \mathrm{N}$ and between $40^{\circ} \mathrm{W}$ and $75^{\circ} \mathrm{W}$ (Fig. 1), the Pleistocene sediments are characterized by the occurrence of various amounts of random illitevermiculite mixed layers $(\mathrm{I}-\mathrm{V})$. The percentages of random I-V mixed layers range from trace amounts to $32 \%$ of the clay mineral fraction. Chamley et al. (1983) interpreted the occurrence of the assemblage composed of chlorite, illite and random mixed layers as the result of the late Cenozoic cooling favouring the supply of minerals derived from poorly weathered continental rocks and highlatitude oceanic currents. Fagel et al. (1996) assumed that random I-V mixed layers came from soils developed on muscovite-rich schists throughout the Appalachian region. Vanderaveroet (1996) showed that I-V mixed layers were characteristic of the Pleistocene period and probably resulted from the moderate chemical weathering of illite. Bout-Roumazeilles (1995) revealed that the variations of I-V mixed layers were linked to glacial/interglacial alternations, and seemed to result from modifications in the intermediate water-mass circulation. 


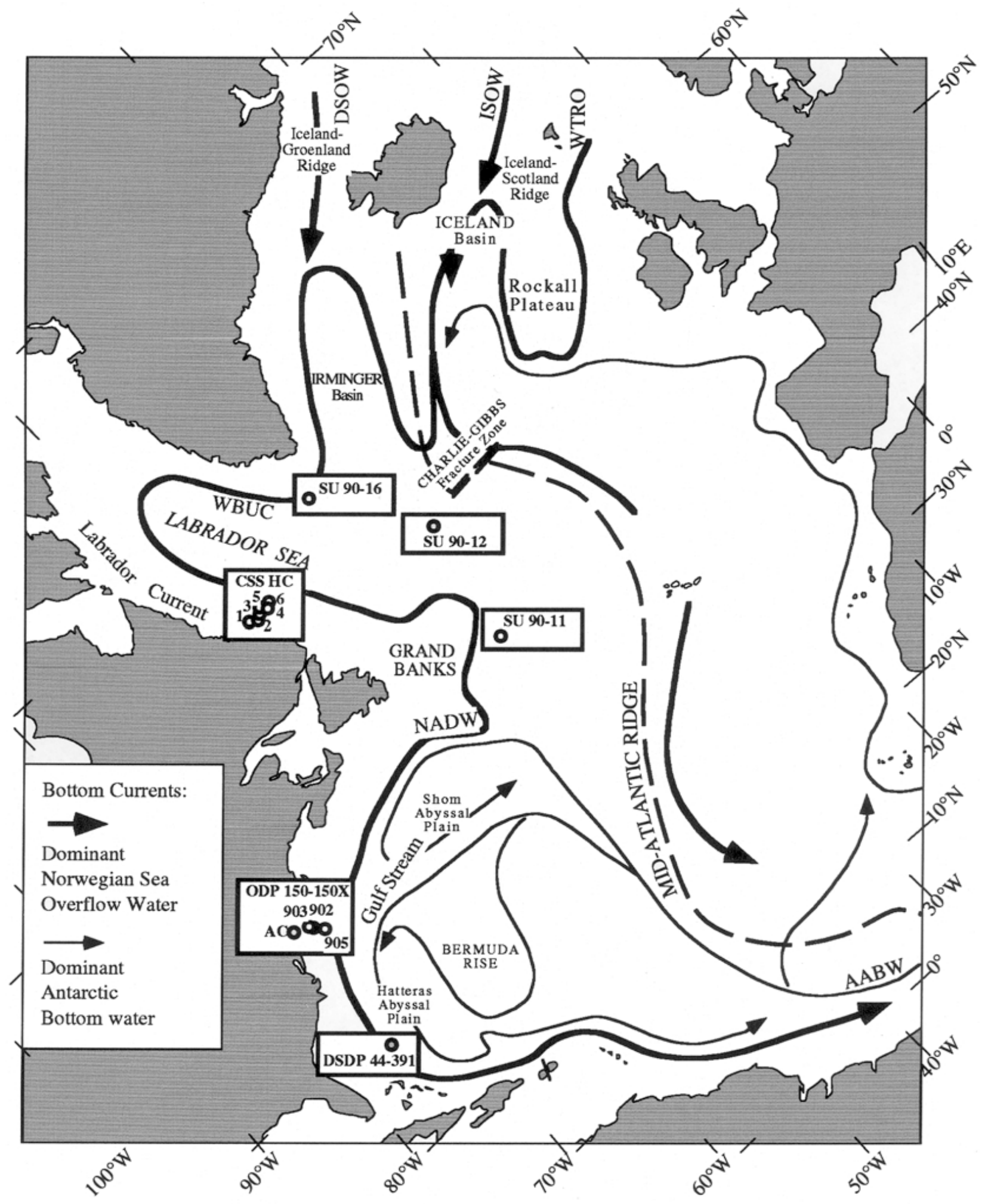

FIG. 1. Location of studied areas and main deep circulation patterns modified from Tucholke et al., 1973; McCave \& Tucholke, 1986; Vogt \& Tucholke, 1989. DSOW (Denmark Strait Overflow Water), ISOW (Iceland- Scotland Overflow Water), and WTRO (Wyville-Thomson Ridge Overflow Water) combine to form NADW (North Atlantic Deep Water) and WBUC (Western Boundary Undercurrent). AC = Atlantic City Borehole. 
The I-V mixed layers are present in some old sedimentary rocks (Cretaceous to Cenozoic sediments) which have been affected by burial diagenesis (e.g. Kafoutine borehole, coastal basin of Senegal; ODP site 652, Leg 107, western Tyrrhenian Basin (Chamley \& Debrabant, 1989)) but they have rarely been reported in Pleistocene marine sediments, including those of the North Atlantic Ocean. Various questions therefore arise about the formation, transport and significance of these I-V mixed layers.

In this paper we reassess the formation, the transport and the distribution of illitevermiculite mixed-layer clay minerals, and their relation to climate changes as well as to deep and surface oceanic circulation during the Pleistocene.

\section{MATERIALS AND METHODS}

The analyses were performed on samples from sites 902 to 905 and Atlantic City Borehole (Legs 150 and 150X, New Jersey margin), sites 1, 2, 3, 4, 5 and 6 (CSS Hudson cruise 91-045, Labrador Sea), core SU 90-11 and cores SU 90-12 to 16 (1990 Paleocinat cruise, North American Basin and Labrador Sea).

Deflocculation of clays was carried out by successive washing with distilled water after decarbonatation of the crushed sediment with $0.2 \mathrm{~N} \mathrm{HCl}$. The clay fraction $(<2 \mathrm{~mm})$ was separated by sedimentation and centrifugation (Brown \& Brindley, 1980). The clay mineral phase was determined by using X-ray diffraction (XRD) on oriented mounts. The XRD patterns were obtained using a Philips PW 1730 diffractometer with $\mathrm{Cu}-\mathrm{Ka}$ radiation and Ni filter (40 kV and $25 \mathrm{~mA}$ ). The XRD analyses were performed after air drying, ethylene glycol solvation, and heating at $490^{\circ} \mathrm{C}$ for $2 \mathrm{~h}$. The goniometer scanned from $2.5^{\circ}$ to $28.5^{\circ} 2$ theta for air-dried and glycol-solvated conditions and from $2.5^{\circ}$ to $14.5^{\circ} 2$ theta for heating conditions. The identification of clay minerals was made according to the position of the 001 series of basal reflections (Brown \& Brindley, 1980). Semi-quantitative estimates (Table 1) were based on the intensity and on the area of the main diffraction peak of each mineral (Biscaye, 1965). The reproducibility of the technical work and measurements was tested: five oriented mounts, performed on the same sample, were submitted three times to XRD. The relative error interval is $+5 \%$.

X-ray diffraction analyses allowed us to identify, in addition to the common clay minerals, illite, chlorite, smectite, kaolinite and some random mixed-layered I-V. These I-V 
mixed layers are characterized in air-dried conditions by a broad peak ranging from 10 to $13 \mathrm{~A}^{\circ}$, with a maximum intensity at $\sim 12 \mathrm{~A}^{\circ}$ (Fig. 2). This peak is not altered in position or intensity by glycol saturation but collapses to $10 \mathrm{~A}^{\circ}$ after heating.

For each site the time-scale is based on nanofossil and diatom zonations or on the comparison between the benthic and/or planktonic $\mathrm{d} 180 \mathrm{O}$ records and the spectral mapping SPECMAP stack (Martinson et al., 1987).

\section{RESULTS}

Spatial distribution of illite-vermiculite mixed layers

Northwestern Atlantic Ocean between $45^{\circ} \mathrm{N}$ and $60^{\circ} \mathrm{N}$. The Pleistocene sediments containing I-V mixed layers were drilled at water depths of 530, 301, 340, 1364, 1984 and $2648 \mathrm{~m}$ (HillaireMarcel et al., 1991; Fig. 1) and 2100, 2924, 2950 and 3660 m (Bout-Roumazeilles et al., 1997; Fig. 1). From shelf to rise, the surface sediments of the western Labrador margin consist of brown muddy sand to foraminiferal mud (Fagel et al., 1996). The I-V mixed layers are abundant (up to 35\%) in the shallowest sites (sites 1, 2 and 3) along the western Labrador margin (Fig. 3). At

greater depths, they decrease to $5 \%$ at site 4 , and to trace amounts at sites 5 and 6 . The other clay minerals include chlorite, illite and kaolinite. Smectite is absent in the shallowest sites (sites 1 to 6) whereas its percentage reaches $47 \%$ in the deepest sites where I-V mixed layers are absent (Fagel et al., 1996).

The I-V mixed layers constitute 5\% of the clay fraction in core SU 90-13 located near the entrance of the Labrador Sea at $3660 \mathrm{~m}$ depth, as well as in core SU 90-14 which is located near the southern tip of Greenland at $2924 \mathrm{~m}$ depth. The site SU 90-12 is located near the mouth of the Labrador Sea (Fig. 1) at a water depth of $2950 \mathrm{~m}$ on a seamount developed up to $1000 \mathrm{~m}$ above the seafloor. The Pleistocene- Holocene sediments of core SU 90-12 are composed mainly of dark grey terrigenous muds, interbedded with minor levels of calcareous (nanofossils with foraminifera) muds. The average percentage of $\mathrm{I}-\mathrm{V}$ mixed layers is $18 \%$ (Fig. 3, Table 1). The site SU 90-16 is located at the southern Greenland shelf edge at a water depth of $2100 \mathrm{~m}$ (Fig. 3). The Pleistocene- Holocene sediments are composed of terrigenous muds interbedded with silty to sandy layers. Illitevermiculite mixed layers (11\%) are associated with chlorite, illite, smectite and 
kaolinite (Bout- Roumazeilles et al., 1997). Holocene sediments are considerably enriched in I-V mixed layers with a maximum of $35 \%$ of the clay mineral association (Table 1).

The site SU 90-11 is located off Newfoundland at a water depth of $3645 \mathrm{~m}$. The Pleistocene-Holocene sediments are dark grey terrigenous muds interbedded with grey calcareous (nanofossils with foraminifera) muds. The clay fraction of Pleistocene sediments consists of a mixture of chlorite, illite, smectite, kaolinite and I-V mixed layers (Bout-Roumazeilles, 1995).

No I-V mixed layers were identified in the clay fraction of late Pleistocene sediments drilled in the eastern part of the Atlantic Ocean (Irminger, Iceland and Rockall Basins; BoutRoumazeilles, 1995; Fagel et al., 1996).

Mid American Atlantic Ocean. Several sites were drilled on the New Jersey passive margin in the Baltimore Canyon Trough along a transect including the coastal plain, the continental slope and the continental rise (Leg ODP 150; Mountain et al., 1994). The Pleistocene sediments recovered at these sites are composed mainly of grey silty clay on the continental slope (site 902, $811 \mathrm{~m}$; site 903, $445 \mathrm{~m}$ ) and rise (site 905, $2698 \mathrm{~m}$ ), and unconsolidated sands, silts, clays and gravels on the coastal plain (Atlantic City borehole; Miller et al., 1994). The clay minerals in Pleistocene sediments include illite and chlorite, associated with kaolinite, smectite and randomly interstratified minerals such as I-V. The appearance of chlorite and I-V mixed layers characterizes the clay mineralogy of Pleistocene sediments drilled on the continental slope and rise (Deconinck \& Vanderaveroet, 1996; Vanderaveroet, 1996; Vanderaveroet et al., 1999) and on the coastal plain (Vanderaveroet \& Deconinck, 1997). The percentages of I-V mixed layers reach $20 \%$ (average 15\%) on the coastal plain, 30\% (average 11\%) on the continental slope, and 25\% (average 11\%) on the continental rise (Fig. 3, Table 1). On the continental slope at site 902, illite and interstratified minerals (I-V and I-S) are correlated negatively. Variable amounts of quartz, feldspars and amphibole are associated with the clay minerals.

Blake-Bahama Basin. The Pleistocene sediments drilled at $4974 \mathrm{~m}$ depth at site 391 of DSDP Leg 44 are assigned to the 'Blake Ridge Formation'. This formation is composed of silty clay with a small amount of nanofossil and foraminiferal ooze. The clay assemblage is dominated by primary detrital clay minerals such as chlorite and illite, with lesser amounts of several mixed- 
layer minerals (illite- smectite, I-V and chlorite-smectite). The I-V mixed layers, associated with small amounts of smectite, are characteristic of these sediments (Chamley et al., 1983).

\begin{tabular}{|c|c|c|c|c|c|c|c|c|}
\hline Sites & Lat. $\left({ }^{\circ} \mathrm{N}\right)$ & Long. $\left({ }^{\circ} \mathrm{W}\right)$ & $\begin{array}{l}\text { Depth } \\
\text { (m) }\end{array}$ & $\begin{array}{c}\text { Chlorite } \\
(\%)\end{array}$ & $\begin{array}{c}\text { Illite } \\
(\%)\end{array}$ & $\begin{array}{c}\text { Smectite } \\
(\%)\end{array}$ & $\begin{array}{c}\text { Kaolinite } \\
(\%)\end{array}$ & $\begin{array}{l}\text { I-V } \\
(\%)\end{array}$ \\
\hline Core 1 & $54^{\circ} 52^{\prime} 9$ & $56^{\circ} 26^{\prime} 9$ & 530 & 28 & 52 & 0 & 8 & 12 \\
\hline Core 2 & $54^{\circ} 44^{\prime} 5$ & $55^{\circ} 35^{\prime} 0$ & 301 & 25 & 36 & 0 & 7 & 32 \\
\hline Core 3 & $54^{\circ} 49^{\prime} 2$ & $53^{\circ} 43^{\prime} 9$ & 340 & 29 & 36 & 0 & 8 & 27 \\
\hline Core 4 & $54^{\circ} 54^{\prime} 0$ & $52^{\circ} 52^{\prime} 0$ & 1364 & 32 & 54 & 0 & 9 & 5 \\
\hline Core 5 & $55^{\circ} 02^{\prime} 0$ & $52^{\circ} 44^{\prime} 7$ & 1984 & 30 & 60 & 0 & 10 & $\operatorname{Tr}$ \\
\hline Core 6 & $52^{\circ} 07^{\prime} 7$ & $52^{\circ} 07^{\prime} 7$ & 2648 & 41 & 59 & 0 & $\operatorname{Tr}$ & $\operatorname{Tr}$ \\
\hline SU90-11 & $44^{\circ} 43^{\prime} 6$ & $40^{\circ} 15^{\prime} 8$ & 3646 & 20 & 35 & 16 & 12 & 17 \\
\hline SU90-12 & $51^{\circ} 52^{\prime} 6$ & $39^{\circ} 47^{\prime} 4$ & 2950 & 21 & 34 & 15 & 12 & 18 \\
\hline SU90-13 & $52^{\circ} 52^{\prime} 4$ & $41^{\circ} 15^{\prime} 7$ & 3660 & 17 & 42 & 20 & 16 & 5 \\
\hline SU90-14 & $57^{\circ} 39^{\prime} 2$ & $46^{\circ} 51^{\prime} 2$ & 2924 & 12 & 25 & 46 & 12 & 5 \\
\hline SU90-16 & $58^{\circ} 13^{\prime} 2$ & $45^{\circ} 10^{\prime} 5$ & 2100 & 11 & 21 & 44 & 13 & 11 \\
\hline 150X-Atl. City & $39^{\circ} 22^{\prime} 7$ & $74^{\circ} 25^{\prime} 4$ & 0 & 19 & 26 & 35 & 5 & 15 \\
\hline $150-902 \mathrm{D}$ & $38^{\circ} 56^{\prime} 08$ & $72^{\circ} 46^{\prime} 37$ & 808 & 27 & 44 & 10 & 8 & 11 \\
\hline $150-905 \mathrm{~A}$ & $38^{\circ} 36^{\prime} 83$ & $72^{\circ} 17^{\prime} 02$ & 2698 & 23 & 36 & 22 & 8 & 11 \\
\hline
\end{tabular}

$\operatorname{tr}=$ trace amounts

TABLE 1. Core characteristics and average percentages of clay minerals in the fine fraction of sediments from CSS Hudson cruise 91-045 (Fagel et al., 1996), cores SU 90-11 to SU 90-16 from Paleocinat I cruise (Bout-Roumazeilles, 1995) and from ODP sites 150X, 150-902 and 150-905 (Vanderaveroet, 1996; Deconinck \&Vanderaveroet, 1996).

\section{DISCUSSION}

Clay sedimentation in the northwestern Atlantic Ocean is mainly controlled by detrital supply from the North American continent (Biscaye, 1965). Clay mineral particles are transported from continental masses to the ocean by surface and bottom currents (Heezen et al., 1966), and by winds (Grousset \& Biscaye, 1989).

\section{Oceanographic conditions at deep and intermediate depths}

In the North Atlantic two important deep currents control the oceanographic circulation, i.e. the North Atlantic Deep Water (NADW) and the Antarctic Atlantic Bottom Water (AABW) (Fig. 1). Most North Atlantic Deep Water is sourced in the Norwegian Sea as overflow both between Iceland and Greenland through the Denmark Strait (Denmark Strait Overflow Water, DSOW) and between Iceland and Scotland (Iceland-Scotland Overflow Water, ISOW) (McCave $\&$ Tucholke, 1986). At the southern tip of Greenland, the combination of these deep water masses 
(DSOW, ISOW and WTRO) forms a bottom current called the Western Boundary Undercurrent (WBUC) (McCave \& Tucholke, 1986).
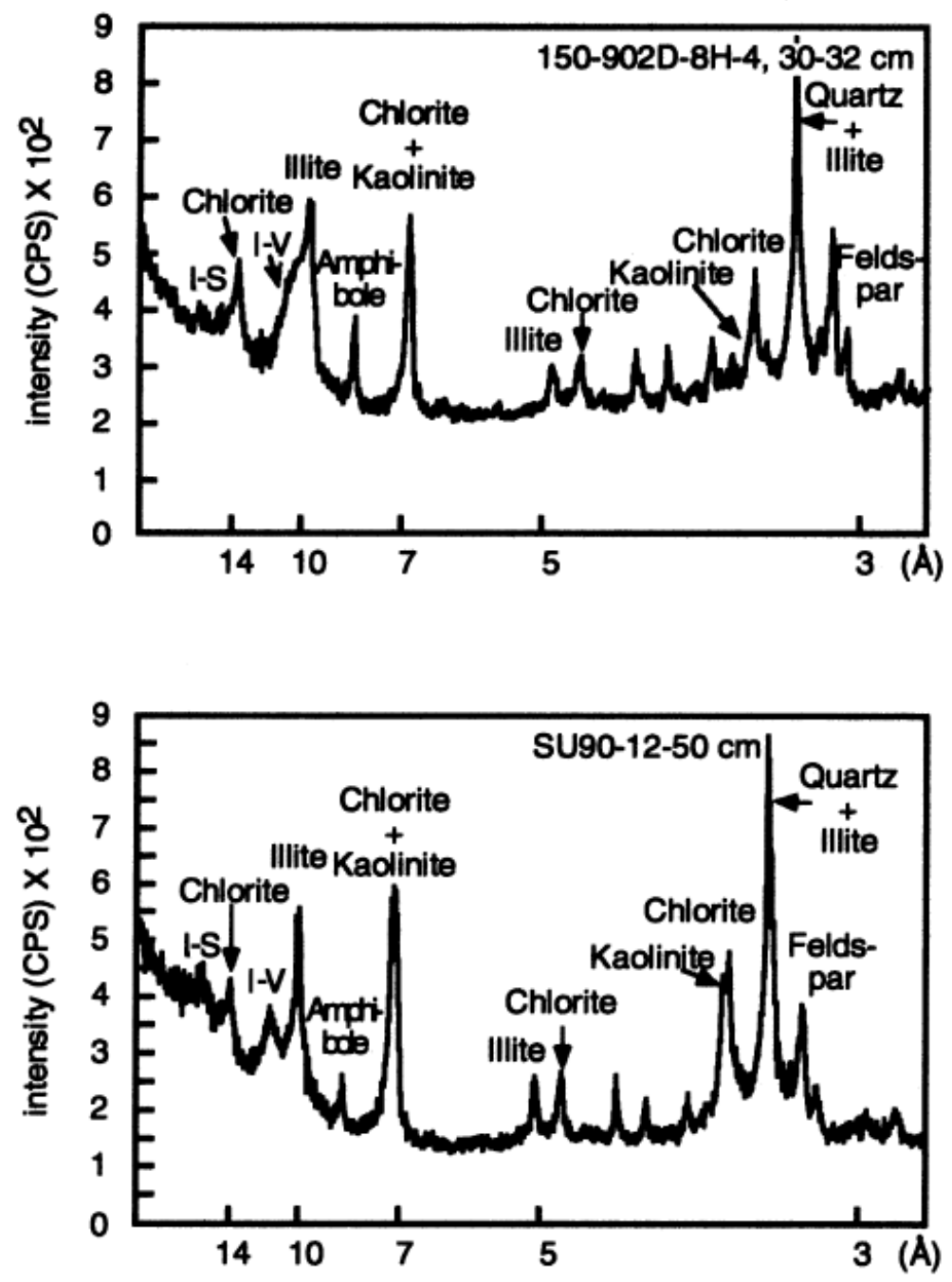

FIG. 2. Typical XRD patterns (glycolated fine fraction) from ODP site 902 (New Jersey continental slope) and Core SU90-12 (Shom Abyssal Plain) sediments. I-S: illite-smectite mixed layers and I-V: illite-vermiculite mixed layers. 
Northern Atlantic Ocean
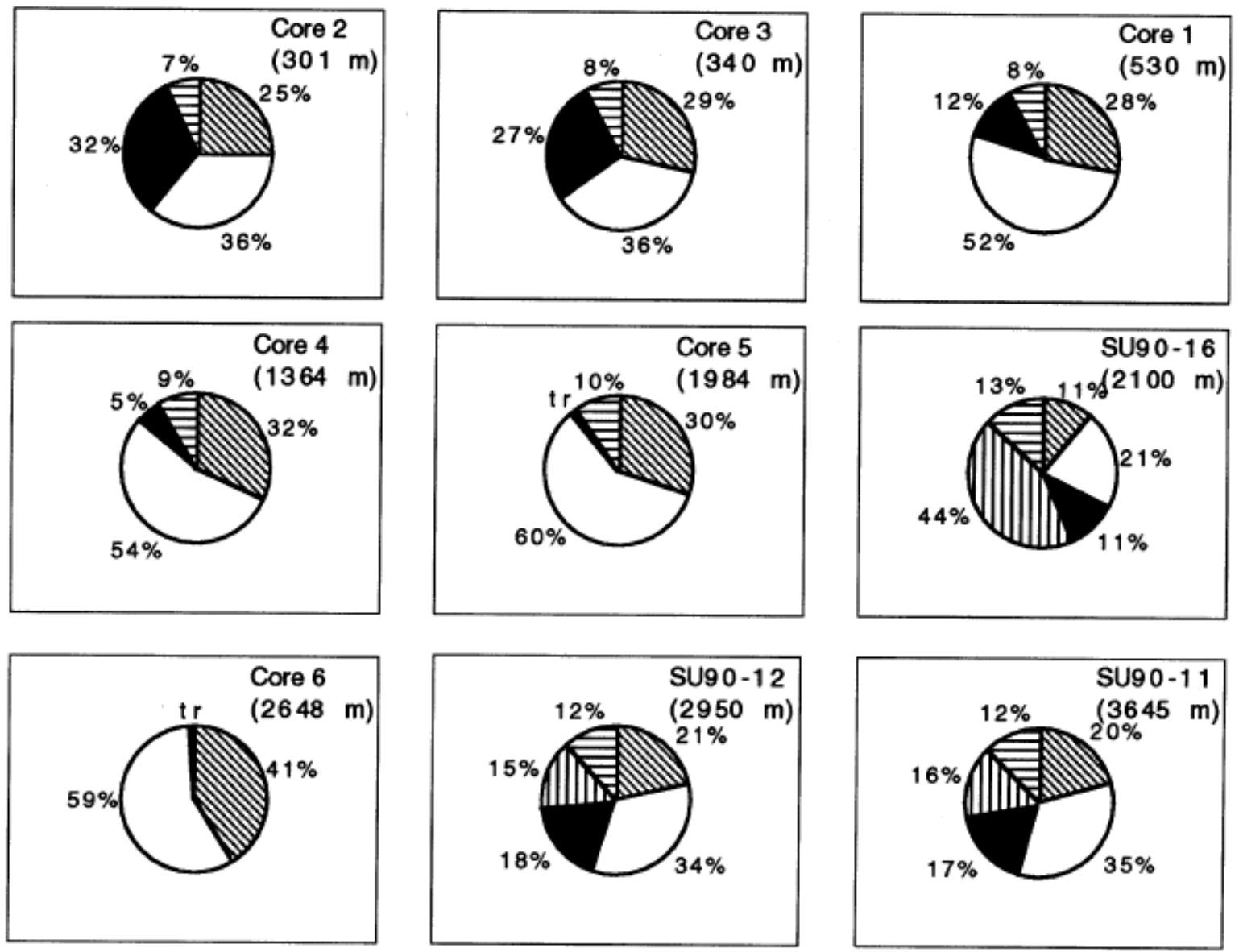

Mid Atlantic Ocean
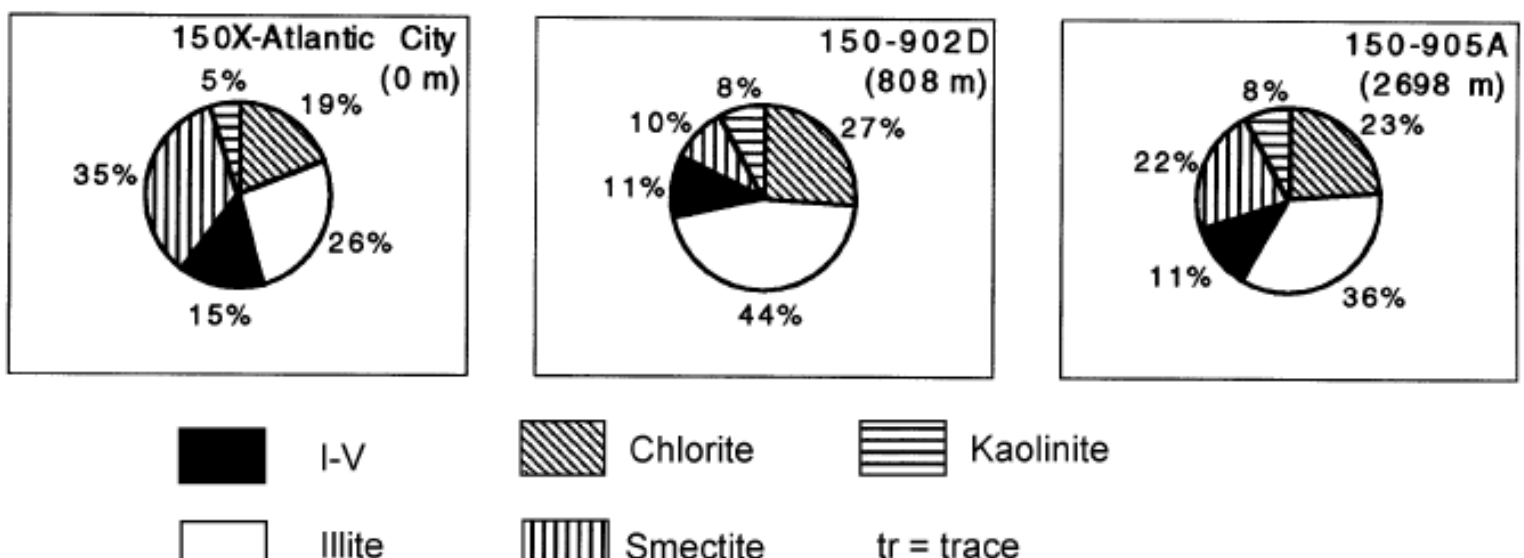

Illite

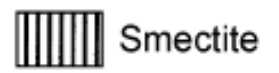

$$
\operatorname{tr}=\operatorname{trace}
$$

FIG. 3. Charts summarizing the mean percentages of clay minerals in the fine fraction at each site. 
The deepest water mass is represented by AABW, entering the western North Atlantic from the south between the Mid-Atlantic Ridge and northern South America (McCave \& Tucholke, 1986).

The North Atlantic Ocean is also characterized by important intermediate-depth currents. In the northwestern Atlantic basin, the main intermediate water mass is the Labrador Intermediate Water flowing at depths ranging from 800 to $2500 \mathrm{~m}$ (Thiébault et al., 1989). This current forms in the Labrador Sea, flows eastwards along the slope and then southwards in the basin at intermediate water depths, following the main pattern of deep-water circulation.

\section{Formation of vermiculite and vermiculitic mixed layers through weathering}

The origin of interstratified clay minerals such as I-V in continental landscapes has been discussed by various authors. Several hypotheses exist to explain the occurrence of vermiculite or vermiculitic mixed-layered minerals in soils:

(1) The weathering of micaceous minerals in soils under temperate climatic conditions can lead to the formation of vermiculitic mixed layers (Berry \& Johns, 1966). The weathering and transformation of a $10 \AA$ mica (biotite or muscovite) into $\mathrm{I}-\mathrm{V}$ has been observed in Adirondack (April et al., 1986), Greenland (Petersen \& Rasmussen, 1980), and Virginia soils (Rich, 1968; McCartan, 1988), and by Harris et al. (1992) in the southern US coastal plain. The random I-V mixed layers are interpreted as having developed as a result of pedogenic processes during the Quaternary under temperate- cool conditions by the transformation of primary minerals, especially of mica-illite, in soils being formed on the Canadian Shield.

The transformation of biotite into a typical Al-rich vermiculite requires a change from a trioctahedral to a dioctahedral structure. This phenomenon has been found for Fe-rich species by Farmer et al. (1971). The removal of the octahedral cations and their replacement by Al, which is especially mobile at low $\mathrm{pH}$, occurs during weathering in acidic soil environments and leads to aluminous, dioctahedral vermiculite. The process involves an exchange of $\mathrm{K}$ by hydrated cations associated with a swelling of the mica. During weathering in acid conditions, considerable interlayer K can be removed from micas in the soil (Rich, 1968).

(2) The formation of mixed layers containing vermiculite-like layers can also be derived from weathering of other primary aluminosilicates (April et al., 1986). For example, the vermiculitization of chlorite is a common phenomenon. The experimental vermiculitization of 
chlorite can be achieved by a thermal dehydroxylation followed by an acid dissolution of the hydroxide sheets, namely via a transitional chlorite/vermiculite stage (Argast, 1991). In the same way feldspar weathering sometimes leads to the formation of vermiculite through an intermediate micaceous phase (April et al., 1986).

\section{Source areas of illite-vermiculite mixed layers}

Illite-vermiculite mixed layers occur in recent northwestern Atlantic sediments, the clay fraction of which is dominated by illite and chlorite (Biscaye, 1965; Hathaway, 1972; Dunn et al., 1987; Deconinck \& Vanderaveroet, 1996) which result predominantly from physical weathering and erosion of continental areas (Biscaye, 1965; Chamley, 1979). On the North American Continent, late Cenozoic glaciers transported southwards large amounts of chlorite and illite eroded from Precambrian and Palaeozoic igneous and sedimentary rocks of the Canadian Shield (Dunn et al., 1987). The association of amphibole and feldspars with chlorite and illite is common and supports the interpretation of glaciers, streams and rivers draining crystalline and metamorphic rocks of the Canadian Shield under glacial climate (Thiébault et al., 1989).

The main sources of I-V mixed layers appear to be located in the North American continent. The I-V mixed layers are particularly abundant on land in the Appalachian mountain range. They were also identified in the northeastern Virginia coastal plain and soils (Rich, 1968; McCartan, 1988); in the external domain of the southern Canadian Appalachians (Yang \& Hesse, 1991) ; in Adirondack soils (April et al., 1986); and in Indiana (Argast, 1991). They are also considered as reworked material in fluvial sediments of Greenland (Petersen \& Rasmussen, 1980).

The negative correlation registered between the abundance of illite and interstratified minerals I-V and I-S in ODP site 902 sediments (New Jersey slope) suggests that both mixedlayered minerals result from weathering of illite (Vanderaveroet, 1996; Vanderaveroet et al., 1999).

Clay mineral transportation 
Rivers. The identification of I-V mixed layers in Atlantic City Borehole sediments recovered in the New Jersey coastal plain (Vanderaveroet, 1996; Vanderaveroet \& Deconinck, 1997) helps us to understand the transport path of these mineral species. The terrigenous sediments offshore New Jersey are transported towards the ocean by the Hudson and Delaware Rivers (Dunn et al., 1987). The palynological data at site Amcor 6021C located on the upper continental slope off New Jersey show that most Quaternary sediments were transported by the Hudson River and its tributaries draining the area between northern New Jersey and eastern Massachussets (Groot et al., 1995). The mineralogical composition of sand-sized sediments from the US middle Atlantic shelf demonstrates the dominant influence of the Hudson River from New York to Cape Hatteras (Darby, 1990). During the Quaternary, the Hudson River drained widely glaciated regions to the north (Poag \& Sevon, 1989; Poag, 1992) and supplied terrigenous material to the coastal plain, outer shelf and upper slope areas off New Jersey (Saito, 1996). The I-V mixed layers were therefore dominantly transported to the ocean by rivers draining the northeastern part of the American continent.

In the Labrador Sea, the offshore position of sites 1, 2 and 3 facing the mouth of the Churchill River suggests that I-V mixed layers were derived from the Canadian Shield, transported to the ocean by rivers draining this area. This is also indicated by the lateral changes in abundance of this clay species (Fagel et al., 1996). The small amounts of I-V mixed layers in sediments at sites 4, 5 and 6 are attributed to the reworking of sediments from shallower sites.

Intermediate water. The occurrence of $\mathrm{I}-\mathrm{V}$ mixed layers on seamounts, culminating at $1000 \mathrm{~m}$ above the seafloor in the western part of the Atlantic Ocean (i.e. Labrador Sea, SU90-11 and SU90-12), could be explained by their transport by a detached nepheloid layer (BoutRoumazeilles et al., 1999). The seasonal existence of such nepheloid layers is documented by Biscaye \& Eittreim (1974). Due to the suspended sediment density and the geographical distribution of water circulation, the nepheloid layers flowed southward at intermediate depths along the western Atlantic passive margin. The suspended sediment content of this nepheloid layer must have increased during short-time climatic events like Heinrich Events, during which the growth and fragmentation of the Laurentide icesheet favoured the reworking of sediments deposited on continental shelves. In the Labrador Sea, the shallow sediments were enriched in IV mixed layers (Fagel et al., 1996) transported to the shelf area by runoff during interglacial 
periods. These particles have probably contributed to the formation of nepheloid layers which flowed at intermediate depth because of relatively high density.

First, the variation in abundance of the $\mathrm{I}-\mathrm{V}$ mixed layers within glacial/interglacial alternations are likely to have been controlled directly by the precession orbital parameter, since insolation and inferred rainfall changes can affect the pedogenic formation of these minerals which form as a result of weathering. The temporal resolution of the chronostratigraphic scale is higher than the gap between continental climatic modifications and their oceanic record. Second, changes in surface and intermediate depth circulation may also have indirectly monitored variations in the mixed-layer I-V supply with a precessional cyclicity ( $\sim 23000$ years). The reworking of this mineral from land masses surrounding the Labrador Sea could have increased during the continental ice-sheet melting induced by precession driven poleward heat transfer. This implies that both insolation and oceanic transport potentially controlled the variations of the mixed-layer I-V supply to the northwestern Atlantic Ocean (Bout-Roumazeilles et al., 1997).

The fact that the mixed-layer I-V content is lower in Holocene sediments of core SU 90$13(5 \%)$ relative to nearby core SU $90-12$ (20\% for sediments of the same stratigraphic level; Table 1, Fig. 1), and similarity of core SU 90-14 (5\%) relative to the very near core SU 90-16 (35\%), seems to be related to the respective core depths. Core SU 90-13 (3660 m depth) is deeper than core SU 90-12 (2950 m), and core SU 90-14 (2924 m) is deeper than core SU 90-16 (2100 $\mathrm{m})$. The correspondence between the core depths and the mixed-layer I-V abundance in the clay mineral association suggests that this mineral group is preferentially transported by intermediate water which develops at water-depths $>2000 \mathrm{~m}$ and flows from the Canadian continental shelf area to the Labrador Sea (Bout-Roumazeilles, 1995).

Bottom water. Illite-vermiculite mixed layers occur locally at sites in areas under the influence of bottom current. Site SU 90-16, for example, situated at the southern Greenland shelf edge; ODP 905, located on the New Jersey upper rise; and DSDP site 391, drilled in the BlakeBahama Basin, are under the influence of the NADW/WBUC (Fig. 1). At DSDP site 391, the mixed layers are scoured from the North Appalachian range. At ODP site 905, they are attributed to transport by the WBUC (Vanderaveroet, 1996; Deconinck \& Vanderaveroet, 1996), as well as by intense winnowing of the adjacent slope. Submarine barrier. Until now, I-V mixed layers have been identified only in the western basins of the North Atlantic Ocean. The clay mineral analyses performed on Pleistocene sediments from sites SU 90-08 (west limb of the Mid-Atlantic Ridge), 
SU 90-33 (off Iceland), and SU 90-38 (off Ireland) (Bout-Roumazeilles, 1995), as well as on surface sediments at sites drilled in Irminger and Iceland basins (Fagel et al., 1996), do not reveal the occurrence of these mixed layers. This suggests that during Quaternary times the MidAtlantic Ridge acted as a barrier for the transport of these clay minerals.

\section{Climatic interpretations}

It is noteworthy that these I-V mixed layers are especially abundant in interglacial deposits, at the expense of smectite. In addition, the highest mixed-layer I-V percentages are observed in Heinrich levels (Bout-Roumazeilles, 1995; Fig. 4a), which characterize abrupt climatic changes during the last glacial period (stages 2,3 and 4) and correspond to the instability of the Laurentide ice sheet (Bond et al., 1992). The border of the Laurentide ice sheet fractured and released icebergs bearing detrital particles from the Canadian Shield. These Heinrich levels are expressed by the occurrence of an increase of the coarse detrital fraction in oceanic sediments (Grousset et al., 1993).

As in the eastern North Atlantic Ocean, the highest proportions of I-V mixed layers in Pleistocene sediments drilled on the New Jersey passive margin are recorded in sediments deposited during interglacial periods and especially during isotopic stages 5 and 7 (Vanderaveroet, 1996; Vanderaveroet et al., 1999; Fig. 4b).

\section{CONCLUSION}

The clay mineral associations of recent and Pleistocene sediments of the northwestern Atlantic Ocean, investigated from cored and drilled material located at various water depths between $30^{\circ} \mathrm{N}$ and $60^{\circ} \mathrm{N}$ and between $30^{\circ} \mathrm{W}$ and $70^{\circ} \mathrm{W}$, comprise, besides common clay species (illite, chlorite, kaolinite, smectite), a random illite-vermiculite mixed-layered mineral characterized by an XRD peak at $12 \AA$ when air dried and glycolated, collapsing to $10 \AA$ after heating. The comparison of new results with previous data leads to the following interpretations.

(1) The presence of I-V mixed layers is characteristic of northwestern Atlantic basins. It has not been reported so far from northeastern Atlantic basins. The mid-Atlantic ridge seems to 
have acted as a barrier and to have prevented the transportation of this mineral into eastern basins.

(2) The I-V mixed layers characterize Pleistocene sediments particularly those deposited during interglacial periods. Since the abundance of I-V mixed-layer minerals are often negatively correlated with those of illite, they are probably derived from the continental weathering of micaceous phyllosilicates, under typically interglacial climatic conditions.

(3) Mineralogical data and geographical distribution indicate that I-V mixed-layered minerals have derived mainly from the Canadian Shield where there were suitable weathering conditions (hydrolysis in rather alkaline environment of old plutonic rocks). The I-V mixed layers may occur in areas submitted to interglacial/glacial variations and where the dominant sediment source comprises micaceous phyllosilicates.

(4) The I-V mixed layers occur in quite different areas and geographical settings and therefore result from different transportation vectors. In the Labrador Sea they are attributed to transfer by intermediate-depth water masses. By contrast the deep to bottom water masses seem to have prevailed in the North American basin because I-V mixed layers are absent from the deepest cores of this region. Further south, the I-V mixed layers result from a direct supply by rivers to the ocean.

(5) Because of their increased supply during interglacial periods, wide transport by intermediateand deep-water masses, and by rivers, the occurrence of these I-V mixed layers can be used as a palaeoclimate proxy in Pleistocene sediments from the northwestern Atlantic Basin.

\section{ACKNOWLEDGMENTS}

We thank P. Recourt for his assistance with the XRD. The coring cruise Paleocinat I of the French R/V Le Suroit was supported by INSU-CNRS and IFREMER. This work was supported financially by the EEC program 'Environment and Climate' (ENV4-CT95-0131) and by the UMR 8577 CNRS Sédimentologie et Géodynamique. 


\section{a}

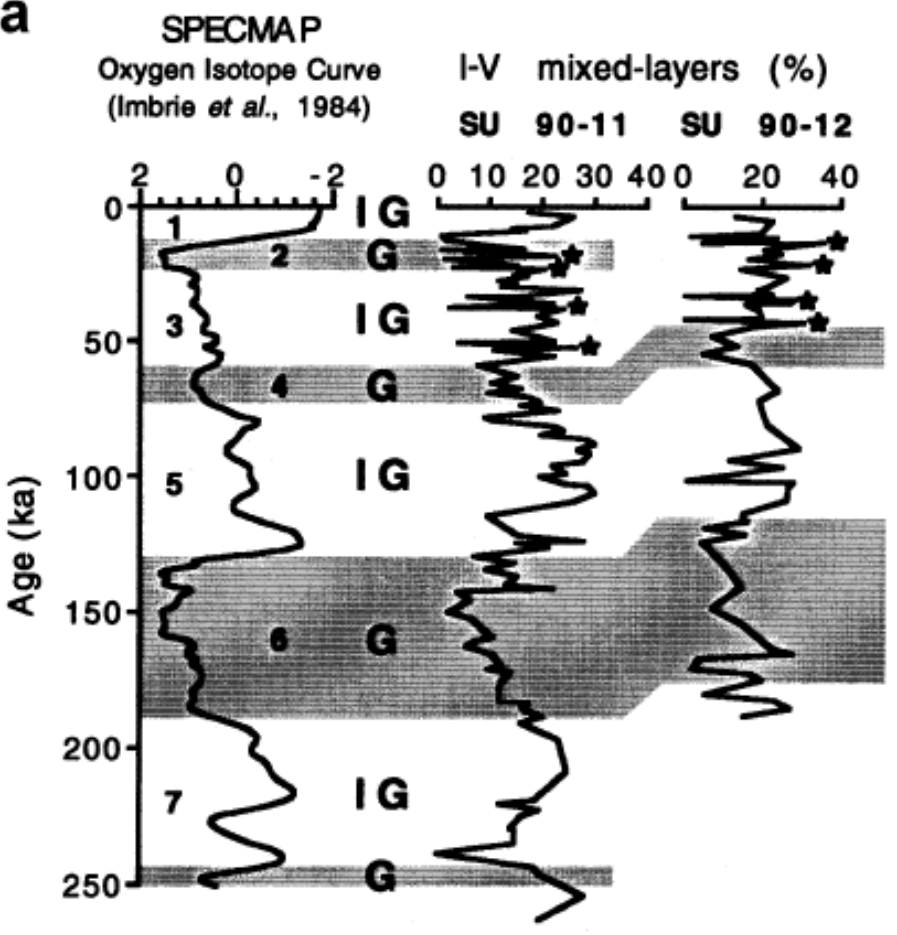

b

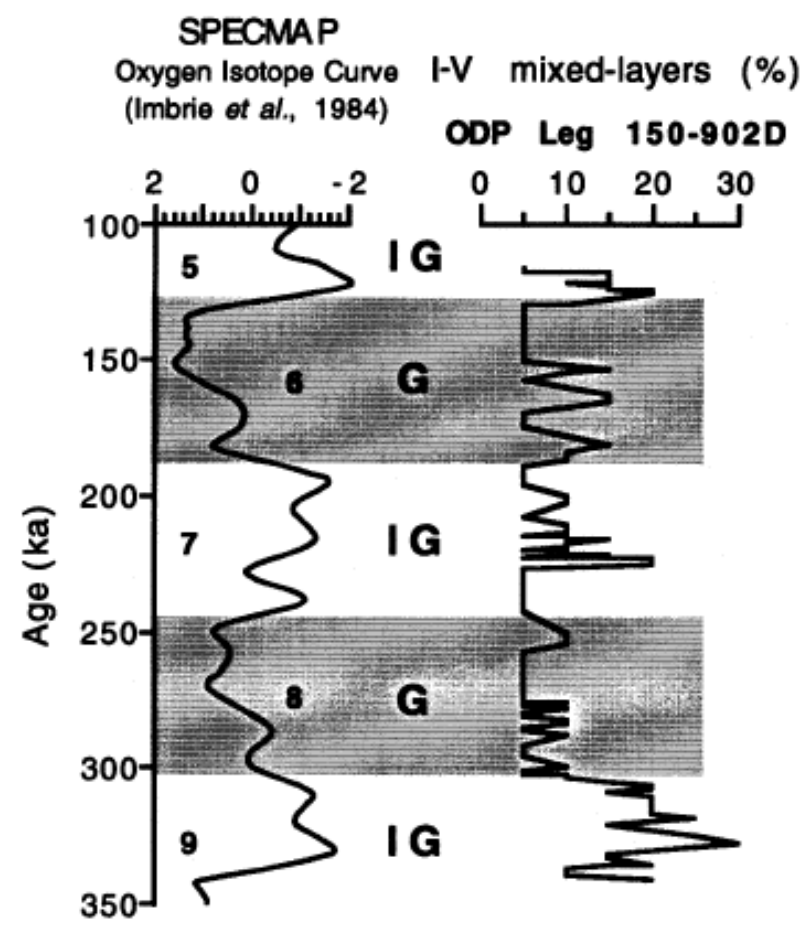

FIG. 4. Correlation between Oxygen Isotopic Curve (SPECMAP, Imbrie et al., 1984) and percentages in the fine fraction of illite-vermiculite mixed layers at (a) Cores SU90-11 (off Newfoundland) and -12 (Shom abyssal plain); and (b) ODP site 902 (New Jersey continental slope). G = Glacial isotopic stage, IG = Interglacial isotopic stage, $\star$ $=$ Heinrich level. 


\section{REFERENCES}

April R.H., Hluchy M.M. \& Newton R.M. (1986) The nature of vermiculite in Adirondack soils and till. Clays Clay Miner. 34, 549-556.

Argast S. (1991) Chlorite vermiculitization and pyroxene etching in an aeolian periglacial sand dune, Allen County, Indiana. Clays Clay Miner. 39, 622-633.

Berry R.W. \& Johns W. (1966) Mineralogy of the clay size fractions of some North Atlantic Arctic Ocean bottom current. Geol. Soc. Am. Bull. 77, 183-196.

Biscaye P.E. (1965) Mineralogy and sedimentation of recent deep-sea clay in the Atlantic ocean and adjacent sea and oceans. Geol. Soc. Am. Bull. 76, 803-831.

Biscaye P.E. \& Eittreim S.L. (1974) Variations in benthic boundary layers phenomenon: Nepheloid layers in the North American Basin. Pp. 227-260 in: Suspended Solids in Water (R.J. Gibbs, editor). Plenum Press, New York.

Bond G., Heinrich H., Broecker W., Labeyrie L., McManus J., Andrews J., Huon S., Jantschick R., Clasen S., Simet C., Tedesco K., Klas M., Bonami G. \& Ivy S. (1992) Evidence for massive discharges of icebergs into the North Atlantic Ocean during the last glacial period. Nature, 360, 245-249.

Bout-Roumazeilles V. (1995) Relations entre variabilités minéralogiques et climatiques enregistrées dans les sédiments de l'Atlantique Nord pendant les huit derniers stades glaciairesinterglaciaires. Thesis, Univ. Lille I, France.

Bout-Roumazeilles V., Debrabant P., Labeyrie L., Chamley H. \& Cortijo E. (1997) Latitudinal control on astronomical forcing parameters on the highresolution clay mineral distribution in the $45^{\circ}-60^{\circ} \mathrm{N}$ range in the North Atlantic Ocean during the past 300,000 years. Paleoceanography, $12,671-686$.

Brown G. \& Brindley G.W. (1980) X-ray diffraction procedures for clay mineral identification. Pp. 305-359 in: Crystal Structures of Clay Minerals and their X-ray Identification (G.W. Brindley \& G. Brown, editors). Mineralogical Society, Monograph, 5, London.

Cassat G. (1979) X-ray mineralogy from Holes 399, 400, 400A, 401, 402, and 402A of Bay of Biscay. Pp. 649-663 in: Init. Repts. DSDP, 48 (L. Montadert, D.G. Roberts et al., editors). U.S. Govt. Printing Office, Washington D.C. 
Chamley H. (1979) North Atlantic clay sedimentation and paleoenvironment since the late Jurassic. Pp. 342-361 in: Deep Drilling Results in the Atlantic Ocean: Continental Margins and Paleoenvironment (M. Talwani, W. Hay \& W.B.F. Ryan, editors). Am. Geophysical Union.

Chamley H. \& Debrabant P. (1989) Diagenèse d'enfouissement et diagenèse thermique. Effets sur les silicates argileux. C. R. Acad. Sci. Paris, 308, 389-394.

Chamley H., Debrabant P., Foulon J., Giroud d'Argoud G., Latouche C., Maillet N., Maillot H. \& Sommer F. (1979) Mineralogy and geochemistry of Cretaceous and Cenozoic Atlantic sediments off the Iberian Peninsula (Site 398, DSDP Leg 47B). Pp. 429-449 in: Init. Repts. DSDP, 47, Part 2 (J.C. Sibuet, W.B.F. Ryan et al., editors). U.S. Govt. Printing Office, Washington D.C.

Chamley H., Giroud d'Argoud G. \& Robert C. (1980) Clay mineralogy of Cretaceous and Cenozoic sediments off the Moroccan margin, Deep Sea Drilling Project Sites 415 and 416. Pp. 715-723 in: Init. Repts. DSDP, 50 (Y. Lancelot, E.L. Winterer et al., editors). U.S. Govt. Printing Office, Washington D.C.

Chamley H., Debrabant P., Candillier A.M. \& Foulon, J. (1983) Clay mineralogical and inorganic geochemical stratigraphy of Blake-Bahama Basin since the Callovian, Site 534, Deep Sea Drilling Project Leg 76. Pp. 437-451 in: Init. Repts. DSDP, 76 (R.E. Sheridan, F.M. Gradstein et al., editors). U.S. Govt. Printing Office, Washington D.C.

Darby D.A. (1990) Evidence for the Hudson River as the dominant source of sand on the US Atlantic Shelf. Nature, 346, 828-831.

Deconinck J.F. \& Vanderaveroet P. (1996) Eocene to Pleistocene clay mineral sedimentation off New Jersey, Western North Atlantic (ODP Leg 150, sites 903 and 905). Pp. 147-170 in: Proc. ODP, Sci. Results, 150 (G.S. Mountain, K.G. Miller, P. Blum, C.W. Poag \& D.C. Twichell, editors). College Station, TX (Ocean Drilling Program).

Dunn D.A., Patrick D.M. \& Cooley U. Jr. (1987) Cenozoic clay mineralogy of Sites 604 and 605, New Jersey Transect, Deep Sea Drilling Project Leg 93. Pp. 1023-1037 in: Init. Repts. DSDP, 93 (J.E. van Hinte, S.W. Wise, Jr. et al., editors). U.S. Govt. Printing Office, Washington D.C.

Fagel N., Robert C. \& Hillaire-Marcel C. (1996) Clay mineral signature of the NW Atlantic Boundary Undercurrent. Mar. Geol. 130, 19-28.

Farmer V.C, Russell J.D., McHardy W.J., Newman A.C.D., Ahlrichs J.L. \& Rimsaite J.Y.H. (1971) Evidence for loss of protons and octahedral iron from oxidized biotites and vermiculites. Mineral. Mag. 38, 121-137. 
Flood R. (1978) X-ray mineralogy of DSDP Legs 44 and 44A, Western North Atlantic: lower continental Rise Hills, Blake Nose, and Blake-Bahama Basin. Pp. 515-521 in: Init. Repts. DSDP, 44 (W.E. Benson, R.E. Sheridan et al., editors). U.S. Govt. Printing Office, Washington D.C.

Groot J.J., Benson R.N. \& Weymiller J.F. (1995) Palynological, foraminiferal, and aminostratigraphic studies of Quaternary sediments from the U.S. Middle Atlantic upper continental slope, continental shelf and coastal plain. Quat. Sci. Rev. 14, 17-49.

Grousset F.E. \& Biscaye P.E. (1989) Nd and Sr isotopes as tracers of wind transport: Atlantic aerosols and surface sediments. Pp. 385-400 in : Paleoclimatology and Paleometeorology: Modernand Past Patterns of Global Atmospheric Transport (M. Leinen \& M. Sarnthein, editors). Kluwer Academic Publishers, Norwell, Mass.

Grousset F.E., Labeyrie L., Sinko J.A., Cremer M., Bond G., Duprat J., Cortijo E. \& Huon S. (1993) Patterns of ice-rafted detritus in the Glacial North Atlantic $\left(40^{\circ}-55^{\circ} \mathrm{N}\right)$. Paleoceanography, 8, 175-192.

Harris W.G., Morrone A.A. \& Coleman S.E. (1992) Occluded mica in hydroxy-interlayered vermiculite grains from a highly-weathered soil. Clays Clay Miner. 40, 32-39.

Hathaway J.C. (1972) Regional clay mineral facies in estuaries and continental margin of the United States east coast. Geol. Soc. Am. Mem. 133, 293-316.

Heezen B.C., Hollister C.D. \& Ruddiman W.F. (1966) Shaping of continental rise by deep geostrophic contour currents. Science, 152, 502-508.

Hillaire-Marcel H., De Vernal A., Vallie'res S. et al. (1991) Cruise report and on-board studies, CSS Hudson 91-045, the Labrador Sea, the Irminger and Iceland basins. Geol. Surv. Can., Open file.

Imbrie J., Hays J.D., Martinson D.G., McIntyre A., Mix A.C., Morley J.J., Pisias N.G., Prell W.L. \& Shackleton N.J. (1984) The orbital theory of Pleistocene climate: support from a revised chronology of the marine d180 record. Pp. 269-305 in: Milankovitch and Climate (A. Berger, J. Imbrie et al., editors). Reidel, Dordrecht, The Netherlands.

Koch R. \& Rothe P. (1979) X-ray mineralogy studies - Leg 43. Pp. 1019-1041 in: Init. Repts. DSDP, 43 (B.E. Tucholke, P.R. Vogt et al., editors). U.S. Govt. Printing Office, Washington D.C. 
Lancelot Y. Hathaway J.C. \& Hollister C.D. (1972) Lithology of the sediments from the western North Atlantic, Leg 11, Deep Sea Drilling Project. Pp. 901-949 in: Init. Repts. DSDP (C.D. Hollister, J.I. Ewing et al., editors). U.S. Govt. Printing Office, Washington D.C.

Martinson D.G., Pisias N.G., Hays J.D., Imbrie J., Moore T.C. \& Shackleton N.J. (1987) Age dating and the orbital theory of ice-ages: development of high resolution 0 to 300,000-year chronostratigraphy. Quat. Res. 27, 1-29.

McCartan L. (1988) Geology and paleontology of the Haynesville Cores Northeastern Virginia coastal plain. U.S. Geol. Surv. Prof. Pap. 1489.

McCave I.N. \& Tucholke B.E. (1986) Deep currentcontrolled sedimentation in the western North Atlantic. Pp. 451-468 in: The Geology of North America (Vol. M): The Western North Atlantic Region (P.R. Vogt \& B.E. Tucholke, editors). Geological Society of America, Washington D.C. Miller K.G., Browning J.V., Liu C., Sugarman P.J., Kent D.V., Van Fossen M., Queen D., Goss M., Gwynn D., Mullikin L., Feigenson M.D., Aubry M.P. \& Burckle, L.D. (1994) Atlantic City Report. Pp. 35-55 in: Proc. ODP, Init. Repts., 150X. College Station, TX (Ocean Drilling Program). Mountain G.S., Miller K.G., Blum P. et al. (1994) Proc. ODP, Init. Repts., 150. College Station, TX (Ocean Drilling Program).

Petersen L. \& Rasmussen K. (1980) Mineralogical composition of the clay fraction of the two fluvioglacial sediments from East Greenland. Clay Miner. 15, 135-145.

Poag C.W. (1992) U.S. Middle Atlantic Continental Rise: Provenance, dispersal, and deposition of Jurassic to Quaternary sediments. Pp. 100-156 in: Geologic Evolution of Atlantic Continental Rises (C.W. Poag \& P.C. de Graciansky, editors). Van Nostrand Reinhold, New York.

Poag C.W. \& Sevon W.D. (1989) A record of Appalachian denudation in postrift Mesozoic and Cenozoic sedimentary deposits of the U.S. middle Atlantic margin. Geomorphology, 2, 119-157. Rich C.I. (1968) Hydroxy interlayers in expansible layer silicates. Clays Clay Miner. 16,15-30. Robert C. (1992) Late Eocene-early Oligocene evolution of climate and marine circulation: deepsea clay mineral evidence. The Antarctic paleoenvironment: a perspective on global change. Antarctic Res. series, 56, 97-117.

Saito Y. (1996) Grain-size and sediment-color variations of Pleistocene slope sediments off New Jersey. Pp. 229-239 in: Proc. ODP, Sci. Results, 150 (G.S. Mountain, K.G. Miller, P. Blum, C.W. Poag \& D.C. Twichell, editors). College Station, TX (Ocean Drilling Program). 
Thiébault F., Cremer M., Debrabant P., Foulon J., Nielsen O.B. \& Zimmerman H. (1989) Analysis of sedimentary facies, clay mineralogy, and geochemistry of the Neogene-Quaternary sediments in site 645, Baffin Bay. Pp. 83-100 in: Proc. ODP, Sci. Results, 105 (S.P. Srivastava, M.A. Arthur, B. Clement et al., editors). College Station, TX (Ocean Drilling Program).

Vanderaveroet P. (1996) Contrôle climatique de la sédimentation argileuse cénozoïque sur la marge passive du New Jersey. Thesis, Univ. Lille I, France.

Vanderaveroet P. \& Deconinck J. F. (1997) Clay mineralogy of Cenozoic sediments of the Atlantic City Borehole, New Jersey, Leg ODP 150X. Pp. 49-57 in: Proc. ODP, Sci. Results, 150X (K.G. Miller \& S.W. Snyder, editors). College Station, TX (Ocean Drilling Program).

Vanderaveroet P., Averbuch O., Deconinck J.F. \& Chamley H. (1999) A record of glacial/interglacial alternations in Pleistocene sediments off New Jersey expressed by clay mineral, grain-size and magnetic susceptibility data. Mar. Geol. 159, 79-92.

Vogt P.R. \& Tucholke B.E. (1989) North Atlantic Ocean basin; aspects of geologic structure and evolution. Pp. 53-80 in: The Geology of North America (Vol. A): The Geology of North America - an overview (A.W. Bailey \& A.R. Palmer, editors). Geological Society of America, Washington D.C.

Yang C. \& Hesse R. (1991) Clay minerals as indicators of diagenetic and anchimetamorphic grade in an overthrust belt, external domain of Southern Canadian Appalachians. Clay Miner. 26, 211-231. 